\title{
Financing of Projects of Kosovo Municipalities through Public Debt
}

\author{
Ilire AHMETI ${ }^{\star}$, Betim SPAHIU ${ }^{\star \star}$
}

\begin{tabular}{l}
\hline \multicolumn{1}{c}{ A R T I C L E I N F O } \\
\hline Article history: \\
Accepted August 2020 \\
Available online August 2020 \\
\hline JEL Classification \\
H60, H68, \\
Keywords: \\
Public Debt, Financing, \\
Management, Government, \\
Municipal
\end{tabular}

\section{Introduction}

Debt as an instrument used by the state to meet its extraordinary needs and to finance various investment projects, occupies an important place in almost all developing and underdeveloped countries, especially after the war, in cases of natural disasters, financial crises, etc. Public debts can be taken by legal or natural entities within the state as well as those abroad.

In the Republic of Kosovo, the Government makes the management of state debt, where this has taken the legal basis, as in primary level as well as in the secondary, which are prepared depending on government policies.

Financial institutions or potential creditors, to which Kosovo has access to financing, broken down by type of financing, are as follows:

\section{$>$ Budget Funding}

- International Monetary Fund (IMF),

- World Bank (instrument conditional on achieving certain reforms)

\section{$>$ Project Funding}

- World Bank - International Development Association (IDA)

- European Bank for Reconstruction and Development (EBRD),

- European Investment Bank (EIB),

- German Agency for Reconstruction (KfW),

- Federal Republic of Austria,

- Islamic Development Bank (ISDB),

- Saudi Development Fund (SFD),

- OPEC Development Fund (OFID),

- Japan International Cooperation Agency (JICA)

- Council of the European Development Bank (CEB)

- Other lenders with whom cooperation may be established in the future. 


\section{Methodology}

For the realization of this scientific work, several methods of scientific research have been used. Among the methods, the first is the empirical method according to which the genesis of public debt was studied by the classics and debtors who among the first had given their ideas on public debt. Then the method of analysis and synthesis doing the analysis of municipal debt in particular and public debt in general [3] . Another method that has been used is the specialization method as the paper deals with municipal debt in specifics. However, in order to give full character to this scientific paper, meetings and interviews were held with the main actors of this field in Kosovo, first of all with the Debt Management Unit within the Treasury, the Ministry of Finance of Kosovo, then with various financial officials in some municipalities of Kosovo.

\section{Definition of public debt}

Definition of public debt according to the Law on Public Debt of Kosovo No. 03 / L - 175, debt is any financial obligation to be paid, or otherwise to pay money arising from Financing Contracts, treasury bills, bonds, overdrafts or from other securities transmitted in exchange for the outflow of funds, as well as the obligation to pay principal, interest, deductions, commissions, commissions or fines of any nature.

State debt means any financial obligation that the Government has entered into that includes internal debts, external debts whether they are issued in physical or electronic form.[4] Thus, state debt is money that the state receives from foreign entities, entities or states and which it must repay at the time specified by agreement along with interest or interest.

The state debt is taken for various reasons, among which are:

- covering extraordinary expenses

- non - timely collection of public revenues in relation to public expenditures

- financing of various investment projects

- budget deficit financing

Depending on the duration of the debt repayment, the state debt is divided into:

Short-term debt, which must be returned or paid over a period of time within a year, and

Long-term debt, which debt must be paid in a period longer than one year.

Whereas, depending on the subjects or entities within the territory of the state or on foreign organizations, institutions or governments, the public debt is divided into:

- Domestic debt and

- External debt (international)

\section{Sub-borrowed public debt}

Under-borrowed debt is characterized by 2 processes as follows [5] :

- The first process is when the Government borrows debt from external creditors;

- The second process is when the Government under-lends the borrowed funds to public sector organizations.

In these cases, it first signs the financing agreement with the creditor, and secondly enters into sublending agreements with the public sector organization. Debt settlement by the budget organization is done to the Government, then the Government transfers the amount of debt to the external or internal creditor.

Table 1. Level of under-borrowed debt 2014- Q4 2018

\begin{tabular}{|c|c|c|c|c|c|c|c|c|}
\hline & 2014 & 2015 & 2016 & 2017 & \begin{tabular}{r|} 
TM1 \\
2018
\end{tabular} & $\begin{array}{r}\text { TM2 } \\
2018\end{array}$ & $\begin{array}{l}\text { TM2 } \\
2018 \\
\end{array}$ & $\begin{array}{r}\text { TM2 } \\
2018\end{array}$ \\
\hline International Debt & 326.35 & 371.17 & 373.77 & 422.15 & 415.98 & 418.37 & 416.59 & 416.15 \\
\hline Central Government & 316.54 & 339.87 & 323.93 & 365.18 & 358.55 & 364.03 & 361.85 & 364.53 \\
\hline International Debt & 9.81 & 31.30 & 49.83 & 56.97 & 57.43 & 54.34 & 54.74 & 51.62 \\
\hline $\begin{array}{l}\text { International Debt } \\
(\% \text { of BPV) }\end{array}$ & $5.86 \%$ & $6.39 \%$ & $6.25 \%$ & $6.58 \%$ & $6.26 \%$ & $6.30 \%$ & $6.27 \%$ & $6.27 \%$ \\
\hline
\end{tabular}

\section{Municipal debt}

Municipalities, as public sector organizations, can get into debt to meet their financial needs.

According to the Law on Public Debts, in Kosovo, municipalities can enter into agreements for shortterm and long-term debts, but certain criteria must be met. One of these criteria is unqualified or unqualified opinion[6] , by the Auditor General as part of the statutory statutory audits for the last two consecutive years.

The municipality that has failed to repay the debt may not incur any additional debt for a period of two years after paying that outstanding debt so that no portion is left unfulfilled.

The municipality may not incur any long-term debt for a period of six months prior to the municipal elections. 
Repayment of municipal debt, in accordance with the terms and conditions set, is the sole responsibility of the municipality, unless expressly guaranteed by another legal entity. Municipal debt does not constitute any direct or indirect obligation of the Republic of Kosovo, except when the Ministry of Finance expressly issues written guarantees related to the debt. The municipal debt cannot be taken over by the state without two thirds of the votes of the Assembly.

Municipal debt can be obtained only in the official currency of the Republic of Kosovo.

\subsection{Debtlimitation}

In Kosovo, according to Law No. 03 / L-175, On Public Debts, in no case should the amount of outstanding principal of total debt exceed forty percent (40\%) of Gross Domestic Product (GDP). In the event that Total debt would exceed forty percent (40\%) of the Gross Domestic Product (GDP), the Government will present s Assembly a strategy to bring the total debt under forty percent threshold (40\%) within a year. While according to this law, the limitations of municipal debt are:

- The total stock of short-term and long-term debt, including guarantees, at no time should exceed forty percent (40\%) of accumulated own source revenues and general grants (excluding non-current revenues) for the year fiscal immediately preceding the borrowing.

- In the case of short-term debt in no case can exceed more than five percent (5\%) of total accumulated revenues (excluding those revenues that are not current) for the fiscal year immediately preceding the borrowing short.

- In the case of long-term debt, the amount of debt service to be paid in any year of a long-term debt should not exceed ten percent (10\%) of total accumulated revenues (excluding non-current revenues) for the fiscal year immediately preceding the receipt of long-term debt.

\subsection{Financing of projects of Kosovo municipalities, through public debt}

These are debts that the state entered into to finance various capital investment projects. The Ministry of Finance should thoroughly analyze each proposal for financing a project. A working group should be set up for this, which will review all debt collection projects

All public sector budget organizations have the right to ask for debts to finance an investment project. Therefore, any proposal for investment projects should be submitted to the Ministry of Finance, which then forms a working group, where among this group should be a representative of the relevant organization which has requested funding for a project, as and a representative of the lender. After evaluating the project proposal, the working group recommends the Ministry of Finance, for approval or not, of the state debt.

When approving debt to other organizations, the Ministry of Finance requires public sector organizations to ensure that:

- The required funds should be used only for the required project,

- The Ministry of Finance has access to records or records related to government debt.

\section{State guarantee}

The guarantee is a potential obligation to pay the debt that initially arises as a liability of a third party and that depends on the failure of that third party to make the payment on time or to comply with the terms of the instrument under which such source debt is regulated [7]. All Guarantees entered by the state or municipality must be explicitly stated in writing.

The state guarantee is a possible obligation of the Republic of Kosovo which depends on the financial obligations of another legal entity and becomes part of the State Debt when the party who is responsible for the payment of such financial obligations fails to make the payment on time right. Then, the Government obliges the Ministry of Finance as the authorized responsible for the management of the state debts to take the responsibility for the payment of the debt of the main / primary obligor.

State guarantees should be planned in the annual State Budget Law.

State guarantees issued to public or private entities will include the requirement that the borrower pay a guarantee fee to the Government. The fee level will be calculated based on an analysis of each guarantee share from the total portion of the assumed losses from the guarantee portfolio. Fees paid under the guarantee fee scheme will be included in the budget and will be calculated as a guarantee reserve. Only expenses related to losses related to state guarantees can be covered by this category of commitments. Any amount exceeded in the guarantee commitments at the end of the fiscal year will be transferred to the budget of future years under the same heading of the committed budget.

Borrowers who may be entitled to the state guarantee are [8]:

- public sector organizations; or

- private entities which are financing public infrastructure projects or projects which are related to the economic sector of strategic or social importance to the state. 
The state guarantee will expire when [9]:

- The loan for which the guarantee is given has been paid in full by the borrower;

- The Warranty Terms have expired; or

- Payment is made in full compliance with the terms of the guarantee.

Until the end of 2017, the state guarantee portfolio of the Republic of Kosovo consists of three issued state guarantees.

In 2014, the Ministry of Finance issued the first new state guarantee in the amount of $€ 10$ million, which guarantees DIFK (Kosovo Deposit Insurance Fund) for the credit line provided by the EBRD. This line of credit has served the DIFK to increase the value of secured deposits from 2,000 to $€ 3,000$ per depositor[10].

Whereas, the Republic of Kosovo has issued the second international guarantee during 2016, through which it guarantees the local public enterprise Urban Traffic for the loan provided by the EBRD in the amount of $€ 10$ million.

It is worth mentioning that this loan is guaranteed within the institutions of Kosovo initially, by the Municipal Assembly of Prishtina. This loan envisages the advancement of Urban Traffic in Prishtina.

At the end of 2016, the Republic of Kosovo issued the third state guarantee in the amount of $€ 24$ million, which was made available to DIFK for the second credit line provided by the EBRD. This line of credit is a continuation of the first line of credit that was made available in 2013, for adequate coverage of depositors secured in proportion to the gradual increase provided by law of the coverage limit for each depositor.

Table 2. The structure of the public debt and state guarantees $2009-2017$

\begin{tabular}{|l|c|c|c|c|c|c|c|c|c|}
\hline & $\mathbf{2 0 0 9}$ & $\mathbf{2 0 1 0}$ & $\mathbf{2 0 1 1}$ & $\mathbf{2 0 1 2}$ & $\mathbf{2 0 1 3}$ & $\mathbf{2 0 1 4}$ & $\mathbf{2 0 1 5}$ & $\mathbf{2 0 1 6}$ & $\mathbf{2 0 1 7}$ \\
\hline International Debt & 249.01 & 260.08 & 253.71 & 336.60 & 323.76 & 326.35 & 371.17 & 373.77 & 422.15 \\
\hline Domestic Debt & 0.00 & 0.00 & 0.00 & 73.31 & 152.51 & 256.52 & 377.78 & 478.97 & 574.27 \\
\hline $\begin{array}{l}\text { Total General } \\
\text { Debt }\end{array}$ & 249.01 & 260.08 & 253.71 & 409.92 & 476.27 & 582.87 & 748.95 & 852.74 & 996.42 \\
\hline State guarantees & 0.00 & 0.00 & 0.00 & 0.00 & 0.00 & 10.00 & 10.00 & 20.00 & 44.00 \\
\hline $\begin{array}{l}\text { Total Debt (\% of } \\
\text { BPV) }\end{array}$ & 6.12 & 5.91 & 5.27 & 8.10 & 8.94 & 10.65 & 13.07 & 14.58 & 16.63 \\
\hline BPV & 4,070 & 4,402 & 4,815 & 5,059 & 5,327 & 5,567 & 5,807 & 5,985 & 6,257 \\
\hline
\end{tabular}

Table 3. Detailed presentation of state guarantees

\begin{tabular}{|l|c|c|c|}
\hline & $\mathbf{2 0 1 4}$ & $\mathbf{2 0 1 5}$ & $\mathbf{2 0 1 6}$ \\
\hline State Guarantee & 10.00 & 10.00 & 20.00 \\
\hline Guarantees for the credit birth of FSDK & 10.00 & 10.00 & 10.00 \\
\hline Guarantee for urban traffic Pristina & 0 & 0 & 10.00 \\
\hline $\begin{array}{l}\text { Guarantee for the second credit line for } \\
\text { FSDK }\end{array}$ & 0 & 0 & 0 \\
\hline State guarantees (\% of BPV) & $0.18 \%$ & $0.17 \%$ & 24.00 \\
\hline
\end{tabular}

\section{Debt program}

Debt program means national debt planning and policies based on macroeconomic and fiscal framework. The government is obliged to prepare a program for the state debt every year, no later than December 31, or until the last date of the fiscal year where the fiscal year does not coincide with the calendar year.

In the Republic of Kosovo, the Ministry of Finance is responsible for preparing and providing the state debt program. This ministry has the task of preparing the program and strategy for public debt management. After preparing the program for the state debt, the ministry sends it to the Government for approval then the Government sends it to the Assembly for information.

The State Debt Program will ensure that borrowing needs are covered at the lowest possible cost, with a reasonable level of risk.

The government debt program includes but is not limited to the following information [11] :

- D statement of Government policy goals for debts;

- Debt Management Strategy on how the Government intends to achieve its debt policy goals;

- Standards and targets including specific annual debt limits for each category of International and

Domestic Debt;

- Historical State Debt and Current Unpaid Part and State Guarantees;

- Expected Payments on Guarantees;

- Historical and current debt service for the entire State Debt;

- Proposed State Debt and State Guarantees, including the purposes of such debts; 
- Debt Service Forecasts including proposed debts for the future;

- Historical indicators for debt sustainability and projected debt sustainability analyzes; and

- Review the performance of previous years and any proposed changes to the Debt Management

Strategy.

The annual debt strategy aims to set an orientation so that the Government can meet its budgetary needs, manage debt and develop the domestic securities market. The objectives of the annual debt strategy are[12] :

- Defining government borrowing targets ;

- Presentation of the current debt structure ;

- Risk assessment ;

- Debt sustainability analysis ;

- Borrowing plan for next year ;

The annual debt strategy has the obligation to determine the debt plan which is incurred on behalf of Government institutions. It should also include the total debt, which consists of state and municipal debt as well as guarantees if issued by any Government [13].

\section{Findings}

The General State Debt of Kosovo until the end of 2017 consisted of domestic debt and international state debt, as well as three state guarantees. So far, Kosovo has no municipal debt or municipal guarantees issued.

During 2017, international debt in Kosovo have been significant developments in comparison to years prior and, as a result of the disbursements under the program with the International Monetary Fund and disbursement of loans to finance projects.

Kosovo municipalities according to the legislation in force can receive short-term debts and longterm debts.

The Government of Kosovo contracts international gold debt from multilateral and bilateral creditors. The main source of multilateral funding is international financial institutions such as the IBRD, ADA and the IMF to which Kosovo is a member. The IDA loans contracted on terms highly favorable to rates lower fixed interest and long-term maturities. Loans from the IMF programs contracted with shorter periods. Bilateral creditors include Germany's Kreditanstalt für Wiederaufbau (KfW), Austria's UniCredit Bank, Exim Bank on behalf of the Government of Hungary, and NATIXIS on behalf of the French Government. Even those creditors financing with rates lower interest fikse with long maturity periods of 18 to 30 years. Some bilateral loans are offered through a combination package between grants and loans. Depending on the proven and binding policies of the borrowers, most creditors only finance specific projects in certain sectors. Borrowing from domestic debt is done through the issuance of securities which differ in maturity. Treasury bills are issued with a maturity of up to 12 months, while Government Bonds, with a maturity of more than 1 year.

All issuance is done in EUR, which eliminates foreign exchange risk, and the funds received are used for direct budget financing. The issuance of securities is characterized by low transaction costs on the one hand, and on the other hand helps the development of the local market by increasing the efficiency of liquidity management, both for the Government and the general financial system.

\section{Recommendations}

We encourage all municipalities in Kosovo to make detailed analyzes of various investment projects and apply for loans (public debt) both internationally and contractually from the Government of Kosovo.

Given the lack of proper analysis of projects or investments by Kosovo municipalities, which would affect local development, our recommendation is that Kosovo municipalities do not start receiving public debt directly, but continue with State guarantees from the Government such as the current situation as well as with under-borrowed debts.

Also, the Government should take measures as soon as possible for investments in local development through domestic public debt through Government securities and through the Kosovo Pension Savings Trust (KPST). So, funds from the KPST to be invested in Kosovo, and not in international markets as has continued so far.

\section{References}

1. Ali J. (2005) "Methodology of Scientific Research Work", Prishtina, Kosovo;

2. Ministry of Finance - Treasury (2011), "Financial management and control", published in cooperation with the European Commission;

3. The Assembly of Kosovo 's (2008), "Law on public financial management and accountability and no. 03 / L-048", Prishtina, Kosovo;

4. Assembly of Kosovo (2010), Law No.03 / L-175 "On Public Debts" Prishtina;

Nexhmije BV (2013) "Public Sector Accounting", Prishtina;

Kosovo Treasury 's (2018), the Division for Management of the Debt "Economic Bulletin 2017 ", Pristina;

International Monetary Fund (2014) "Government Finance Statistics Manual 2014";

Treasury of Kosovo (2018) "State Debt Program 2019-2021", Pristina.

Prof.Dr. Ali Jakupi, Methodology of Scientific Research Work, Prishtina, 2005. 
10. MEF, UdhëzimiAdministrativ No.10 / 2010 on Issuance and Debt Management State and Race in civet United rore, Article 2, Kosovo .

11. Ministry of Finance, Kosovo Treasury, Annual Debt Strategy 2013,

12. Unqualified opinion is when the External Auditor is satisfied with all material aspects relating to the financial statements.

13. Assembly of Kosovo, Law No.03 / L-175, On Public Debt, Article 2, Prishtina, 2010

14. Dr. Nexhmije Berisha Vokshi, Public Sector Accounting, Prishtina, 2013

15. Assembly of Kosovo, Law No. 03 / L-175, On Public Debts, Article 24

16. Kosovo s Treasury, Debt Management Division, Economic Bulletin, 2017, Prishtina, 2018

17. Assembly of Kosovo, Law No.03 / L-175, On Public Debts, Article 15, Prishtina, 2010

18. Annual Debt Strategy 2013, Ministry of Finance, Treasury

19. Dr. Nexhmije Berisha Vokshi, Public Sector Accounting, Prishtina, 2013 